quite the same statement as saying that when that vowel is spoken at all pitches the same cavity is employed.

2. Whether the mouth-cavities for given vowels are supposed to differ phonetically only in respect of pitch of maximum resonance. Helmholtz states clearly that in respect of their pitch of maximum resonance they are different, but he does not clearly say whether or no any other differences are essential. There are passages which seem to show that he considers that any resonator of the required pitch (whether in the least like the mouth in shape or material) would answer as well, or nearly as well, as the special mouth-cavity for the production of a given vowel. On the other hand it is at least conceivable that the cavity for, say, $o$ may be very different from that for $a$ in other respects than simply in the pitch of maximum resonance. As to this we find no statement in the "Tonempfindungen."

In fine we do not see that Prof. Helmholtz, although he has largely added to our knowledge concerning vowels, has laid down any law by which, given the pitch at which any one vowel is to be spoken, the reinforcement of its constituent tones could be even roughly predicted. This prediction could, however, be ronghly made upon the constant-eavity theory, and has been made by Mr. Ellis in his valuable additions to the translation of Helmholtz's work. Prof. Helmholtz seems to do little more than tell us the constituents of a series of vowels sung or said on two notes of one scale, cotpled with one peculiarity and in some cases two peculiarities of the resonance cavity. He has avoided all general conclusions except that quoted above, which states that the vowel peculiarity depends chiefly on the absolute, and not on the relative pitch of the partials.

In our next communication we hope to be able to state how far the information we have derived by means of the phonograph contradicts, supports, or supplements the above theories.

Edinburgh, May 29

FLEEMING JENKIN

J. A. EWING

\section{Extinct and Recent Irish Mammals}

I BEG to thank Prof. Leith Adams for his criticism, in NAtURe, vol, xviii., p. I4I, of my "Preliminary Trentise on the Relation of the l'leistocene Animals to those now living in Europe" (Palccon. Soc., 1878), in which, from the nature of the work, it is impossible that mistakes should not be. I camnot, however, plead guilty to some of the mistakes which are placed to my credit:-I. That "the Irish elk is placed among the pre-historic mammals in consequence of its presence in the peat-bors of England, Scotland, and Ireland," What I wrote (p. 6) was that the presence of the extinct Irish elk in the peat-bogs, which are of well-ascertained pre-historic age, renders it impossible to accept Sir Charles Lyell's definition of the term recent, in which no extinct species are stated to occur.

Of course the Irish elk, as Prof. Leith Adams remarks, has long been known to be met with, almost universally, in the lacustrine marls underlying the peat, and it is thus described in p. 27 of Mr. Sanford's and my own Introcluction (Palcon. Soc., r866). I do not know of its occurrence anywhere in peat, but at the bottom of peat-bogs, to which the bones of animals suffocated in the peat in all probability gravitate. It seems to me very unlikely that all the remains at the bottom of peat-bogs belon to a period before the peat was accumulated.

2. I have never held, and still less to my knowledge printed, that "man and Irish elk, reindeer, mammoth, horse, and bear, were contemporaneous in Ireland." Evidence of palæolithic man, the contemporary of the mammoth in Ireland, is, so far as I know, altogether wanting. If Prof. Leith Adams will kindly write me a reference to any such statement of mine it shall be corrected at once,

My list of Irish animals, which merely purports to give the principal historic mammalia, does not profess to give all the mammalia, which will doubtless be fully treated in Prof. Leith Adams' promised work.

Owens College, Manchester, June 9

\section{Alternate Vision}

Mr. Galton's remark (Nature, vol. xviii. p. 98), that "sometime; the image seen by the left eye prevails over that seen by the right, and vice verst," leads me to describe a curious defect in my own eyesight, which in a different way confirms what he says. While my right cyc is fairly long-sighted, my left eye is very short-sighted. For instance, the focal distance of my right eye for your leader type is 18 inches, and for the left eye only $8 \frac{1}{4}$ inches. For your letter type the focal distance for the one is 16 inches, and for the other $6 \frac{1}{2}$ inches. This is by the light of a Duplex lamp, and by focal distance, I mean the distance at which I can see distinctly. The result of this in equality in my two eyes is that the right-or long-sighted oneinvoluntarily closes when I read, and I am not aware of its being shut, except when some one who is a stranger to the peculiarity calls attention to it. During the day, however, in looking about both eyes are generally open, though when I look intently at a distant view, I find the short-sighted eye shuts occasionally. But in a general way both eyes are open, and I have two distinct images presented to my brain, one blurred and indistinct, even for faces a yard distant, and the other clearly defined, I believe, to the usual distances. How is it that my brain or mind rejects the blurred image and chooses the distinct one, so that I see everything perfectly clearly. If I get a piece of dust in the good eye, or close it, I immediately see the blurred image, and if this take place in the street, it causes a painful degree of confusion as to distances, \&c., so that I am often brought to a standstill by such an occurrence. That both images really are presented to the brain I know. For instance, in travelling by train I frequently amuse myself by placing my eyes so that the short-sighted eye sees a portion of a scene through the window, without the good eye being able to see it. Then I see the blurred image only; but as the train moves the blurred is replaced by the bright one, as the good eye gets to work. The blurred image always appears at a higher level than the other, and it is the same when I shut my good eye for a moment and look at the fire with my bad one. On reopening the good one the blurred fire appears slightly above the bright one, and the latter almost instantly drives the indis. tinct image away-like a dissolving view. 'Things appear, as a rule, much flatter to me than to people who enjoy binocular vision. I know this because I have a pair of spectacles so arranged as to equalise my sights. When I put them on, objects like trees put on a delightfuI fulness and roundness to which am usually quite a stranger, and the effect is most charming. I may add that two of my brothers have a similar defect of vision. May 3 r

J. I. R.

\section{The Eskimo at Paris}

I HAVE read with great interest in vol. xviii. p. I6 of your renowned journal the article concerning the Eslimo, the exhibition of whom in Paris, \&c., has recently made so great a sensation.

Unfortunately, it seems to me, the writer of the article, $M$. A. Borclier, has been incorrectly informed with regard to the introduction of these people. It is not to $\mathrm{Mr}$. Geoffroy St. Hilaire, the director of the Paris Jardin d'Acclimatation, but to M. Charles Hagenbeck, the well-known and inteligent dealer in wild animals of our town, to whom science is indebted for the introduction buth of the Eslimo, the Hamran and other types of the different tribes of Nubia, and the Laplanders.

I should be much obliged to you if you wotld kindly insert the above correction in an early number of your journal.

Hamburg, May 28

J. D. E. SCHMELTZ

\section{The Telephone}

HAVING seen a paragraph in NATURE communicated by $\mathrm{Mr}$. Severn, of Newcastle, New South Wales, describing a methoc of using a telephone to enable deaf persons to hear, I have tried the experiment in the manner Mr. Severn describes-by fastening a string to the parchment cliaphragm of a simple telephone made of wood, and carrying this string round the forehead of the deaf person, who clasps the string with both hands and presses them over his ears. The experiment in this way was partially successful; the sound of the voice was always heard, and some words were distinguished. Afterwards I fastened a single string to the telephone and got the deaf person to hold the string between his teeth. He then heard every word distinctly, even when spoken in a low tone of voice at the whole length of the room.

63, Strand, W.C. JOHN BROWNING.

TILL now I have looked in vain for any account in NATURE of experiments with the telephone or phonoscope, inserted in the circuit of a selenium (galvanic) element (sce NATURE, vol, xvii. P. 3I2).

One is inclined to think that by exposing the selenium to light, 